\title{
EFFECTS OF TEMPORARY UTERINE ISCHAEMIA ON THE RAT EMBRYO AT DIFFERENT MATERNAL ABDOMINAL TEMPERATURES
}

\author{
N. W. BRUCE* \\ School of Veterinary Science, University of Melbourne, \\ Parkville, Victoria, Australia
}

(Received 26th May 1971, accepted 26th Fuly 1971)

\begin{abstract}
Summary. Temporary ischaemia of one uterine horn of anaesthetized, 9-day pregnant rats was induced by occluding the uterine blood vessels with forceps. The effects on the embryo of 30,60 or 120 min of ischaemia was examined with the maternal abdominal temperature maintained at 32,35 or $37^{\circ} \mathrm{C}$.

Ischaemia caused a reduction in fetal survival at all treatment levels. Higher abdominal temperatures caused a greater reduction in fetal survival, as did longer periods of ischaemia. The incidence of fetal malformation was greater in ischaemic than in control horns although specific treatment effects were not apparent. Fetal weights were reduced in the ischaemic horns, especially at the higher abdominal temperatures.

These findings show that abdominal temperature can influence the effects of ischaemia and suggest that the embryo is less resistant to uterine ischaemia than was previously thought.
\end{abstract}

\section{INTRODUCTION}

Occlusion of the uterine blood vessels for $90 \mathrm{~min}$ in the 9-day pregnant rat has been found to cause total embryonic death (unpublished data). This contrasts with an earlier report by Franklin \& Brent (1964) that, at the same stage of gestation, $120 \mathrm{~min}$ of uterine ischaemia caused only a $54 \%$ mortality. Differences in temperature of the embryos may have been responsible since George, Franklin \& Brent (1967) demonstrated that cooling the uterus during ischaemia had a protective influence. The following work was undertaken to examine this possibility and to determine the effect of ischaemia at temperatures similar to that found in the conscious resting animal.

\section{MATERIALS AND METHODS}

Albino Wistar rats with a mean weight of $224 \mathrm{~g}$ were mated overnight and vaginal smears were taken each morning, the day on which spermatozoa were found being designated Day 1 of gestation. On Day 9, each rat was anaesthetized

\footnotetext{
* Present address: The Nuffield Institute for Medical Research, University of Oxford, Osler Road, Headington, Oxford.
} 
by an intraperitoneal injection of $35 \mathrm{mg} / \mathrm{kg}$ Veterinary Nembutal (Abbott Laboratories Ltd), followed by further injections of $10 \mathrm{mg} / \mathrm{kg}$ if necessary. The uterus was exposed by a ventral midline incision, both horns were examined and a record was made of the number and position in the horn of each implantation site. Rats with less than two or more than eight implantation sites in their right horns were discarded at this stage. The rat was transferred to an open box situated beneath two 100-W lamps and a mercury thermometer was placed immediately beneath its right uterine horn and a second thermometer $2 \mathrm{~cm}$ into its rectum. The abdominal incision was covered with plastic film to minimize fluid loss by evaporation and with cotton wool to reduce temperature fluctuations. The lamps were adjusted until the temperature recorded by the abdominal thermometer was stabilized at a predetermined level (it was occasionally necessary to uncover the incision briefly to achieve temperatures as low as $32^{\circ} \mathrm{C}$ ). Dieffenbach's artery forceps, with rubber ensheathed jaws were then positioned quickly around the ovarian and cervical extremities of the right uterine horn so as to enclose and occlude the uterine blood vessels. The mesometrium between the two forceps was incised to ensure that no anastomotic vessels remained. After handling the left horn in a similar manner except for the application of forceps, the incision was again covered and the temperature was re-stabilized within $3 \mathrm{~min}$. After a predetermined period of occlusion at a selected abdominal temperature, the forceps were removed, the incision was closed and the rat was allowed to recover at room temperature. On Day 21 of gestation, 2 days before expected parturition, the rat was killed with an overdose of sodium pentobarbitone and a second examination was made of each conceptus. Each viable fetus was weighed and examined for external malformation as described by Wilson (1965).

The experiment was designed as a $3 \times 3$ treatment factorial with occlusion periods of 30,60 and $120 \mathrm{~min}$, and abdominal temperatures of 32,35 and $37^{\circ} \mathrm{C}$. Five rats were subjected to each of the nine treatment combinations. Three criteria were used to assess the effects on the embryo. (1) Fetal survival rate, which compared the number of live fetuses on Day 21 to the number of implantation sites identified at the time of treatment (a fetus was classified as 'live' if it moved in response to tactile stimuli). (2) Fetal malformation rate, which compared the number of live fetuses with one or more external malformations to the total number of live fetuses recovered on Day 21. (3) The mean fetal weight. Chi-square tests for independence were used to analyse the first two criteria. The difference in mean fetal weight between control and treated horns within each of the nine groups was calculated and the resultant values compared between groups by an appropriate analysis of variance.

The technique for controlling abdominal temperature was tested on twelve non-pregnant rats. It was found that the desired temperatures could be achieved within $5 \mathrm{~min}$ of opening the abdominal cavity. Once stabilized, the abdominal temperature showed little fluctuation; from a total of 198 temperature readings made at 5 -min intervals, 186 were within $\pm 0 \cdot 2^{\circ} \mathrm{C}$, nine within $\pm 0.4^{\circ} \mathrm{C}$, and three within $\pm 0.6^{\circ} \mathrm{G}$ of the selected temperature. The rectal thermometer readings remained within $\pm 1.0^{\circ} \mathrm{G}$ of those measured by the abdominal thermometer. 
To test the efficiency of the occlusion technique, clamps were applied to one uterine horn of each of three rats, after which $1 \mathrm{ml}$ of a $0.2 \%$ Evans blue solution was injected into a saphenous vein. In all three rats, the unclamped horn was coloured by dye within $60 \mathrm{sec}$ of the injection while in the clamped horn, no comparable colour change appeared for at least $10 \mathrm{~min}$. Beyond this time, developing cyanosis prevented further comparison.

In a second test, clamps were applied to one uterine horn of each of twelve non-pregnant rats. Approximately $12.0 \mu \mathrm{Ci}$ radioiodinated human serum albumin were injected into a saphenous vein. At time intervals of 30,60 or $120 \mathrm{~min}$, the section of uterus between the clamps and the equivalent section from the unclamped horn were excised, dissected free from fat and measured

TABLE 1

RADIOACTIVITY RESULTS FROM TESTING THE EFFICIENGY OF THE OCGLUSION TEGHNIQUE

\begin{tabular}{|c|c|c|c|}
\hline \multirow[t]{2}{*}{$\begin{array}{l}\text { No. of } \\
\text { animals }\end{array}$} & \multirow[t]{2}{*}{$\begin{array}{l}\text { Duration of } \\
\text { test }(\min )^{*}\end{array}$} & \multicolumn{2}{|c|}{$\begin{array}{c}\text { Radioactivity of } \\
\text { ischaemic/control } \\
\text { uterine horns }(\%)\end{array}$} \\
\hline & & Mean & Range \\
\hline $\begin{array}{l}3 \\
2 \\
7\end{array}$ & $\begin{array}{r}30 \\
60 \\
120\end{array}$ & $\begin{array}{l}10 \\
16 \\
24\end{array}$ & $\begin{array}{r}6 \text { to } 17 \\
11 \text { to } 20 \\
11 \text { to } 48\end{array}$ \\
\hline
\end{tabular}

* Time interval between injection of isotope and excision of uterus.

for radioactivity. The radioactivities of the clamped horns expressed as percentages of the levels of the unclamped horns are shown in Table 1.

These values increased with time, suggesting a slow leakage of blood through the clamps which can be estimated as follows: if the vascular volume within each uterine horn was $0.02 \mathrm{ml}$ and the flow rate $0.08 \mathrm{ml} / \mathrm{min}$ (values extrapolated from figures given for uteri of non-pregnant rats by Davis (1960) and Csepli, Menyhart, Lengyel, Bodnar \& Turoczi (1968) respectively), then turnover of blood in the control horn was of the order of four times/min. Even after $120 \mathrm{~min}$, the clamped horn contained less than $50 \%$ of the activity in the control horn. Hence, assuming its total blood volume had not diminished, during the 120 -min test period, there was a turnover of less than $50 \%$ of its blood present before isotope injection. With the findings from the Evans blue test, these results confirm the effectiveness of the occlusion technique.

\section{RESULTS}

Uterine ischaemia appeared to have little effect on the mothers; all survived and appeared healthy until the time of autopsy. The uterine horns on gross examination appeared normal with no evidence of damage due to crushing effects of the clamps. There were more implantation sites in the treated horns than in the control horns (234 compared to 184, Table 2 ). This difference was just statistically significant $(P<0.05)$ and, since four rats, each with less than 
two implantation sites per treated horn, were discarded, a small bias towards a higher number of fetuses in the treated horns may have been introduced.

Fetal survival rates from treated horns varied between the nine groups $(P<0.001)$, but values from control horns showed little variation (Table 2$)$ and

TABLE 2

FETAL SURVIVAL RATES AFTER UTERINE ISGHAEMIA AT DIFFERENT ABDOMINAL TEMPERATURES

\begin{tabular}{|c|c|c|c|c|c|c|c|c|c|}
\hline \multirow{4}{*}{$\frac{\text { Treatment }}{\text { Ischaemic horns }}$} & \multirow{4}{*}{$\begin{array}{c}\text { Duration of } \\
\text { stasis (min) } \\
\\
30 \\
60 \\
120 \\
\text { Combined }\end{array}$} & \multicolumn{6}{|c|}{ Abdominal temperature } & \multirow{2}{*}{\multicolumn{2}{|c|}{ Combined }} \\
\hline & & \multicolumn{2}{|c|}{$32^{\circ} \mathrm{C}$} & \multicolumn{2}{|c|}{$35^{\circ} \mathrm{C}$} & \multicolumn{2}{|c|}{$37^{\circ} \mathrm{C}$} & & \\
\hline & & $\begin{array}{r}16 / 27 \\
25 / 31 \\
7 / 23\end{array}$ & $\begin{array}{l}(59) \\
(81) \\
(30)\end{array}$ & $\begin{array}{r}7 / 20 \\
16 / 23 \\
0 / 24\end{array}$ & $\begin{array}{r}(35) \\
(70) \\
(0)\end{array}$ & $\begin{array}{r}17 / 31 \\
2 / 21 \\
0 / 34\end{array}$ & $\begin{array}{r}(55) \\
(10) \\
(0)\end{array}$ & $\begin{array}{r}40 / 78 \\
43 / 75 \\
7 / 81\end{array}$ & $\begin{array}{r}(51) \\
(57) \\
(9)\end{array}$ \\
\hline & & $48 / 81$ & (59) & $23 / 67$ & (34) & $19 / 86$ & (22) & $90 / 234$ & (38) \\
\hline \multirow[t]{2}{*}{ Control horns } & $\begin{array}{r}30 \\
60 \\
120\end{array}$ & $\begin{array}{l}19 / 24 \\
18 / 20 \\
17 / 23\end{array}$ & $\begin{array}{l}(79) \\
(90) \\
(74)\end{array}$ & $\begin{array}{l}15 / 17 \\
14 / 19 \\
14 / 20\end{array}$ & $\begin{array}{l}(88) \\
(74) \\
(70)\end{array}$ & $\begin{array}{l}18 / 20 \\
20 / 26 \\
13 / 15\end{array}$ & $\begin{array}{l}(90) \\
(77) \\
(87)\end{array}$ & $\begin{array}{l}52 / 61 \\
52 / 65 \\
44 / 58\end{array}$ & $\begin{array}{l}(85) \\
(80) \\
(76)\end{array}$ \\
\hline & Combined & $54 / 67$ & (81) & $43 / 56$ & (77) & $51 / 61$ & (84) & $148 / 184$ & (80) \\
\hline
\end{tabular}

$\%$ equivalents in parentheses.

TABLE 3

FETAL MALFORMATION RATES AFTER UTERINE ISCHAEMIA AT DIFFERENT ABDOMINAL TEMPERATURES

\begin{tabular}{c|l|ll|ll|ll}
\hline \multirow{2}{*}{$\begin{array}{c}\text { Duration of } \\
\text { stasis (min) }\end{array}$} & \multirow{2}{*}{$\begin{array}{c}\text { Uterine } \\
\text { horn }\end{array}$} & \multicolumn{5}{|c|}{ Abdominal temperature } \\
\cline { 3 - 7 } & & \multicolumn{2}{|c|}{$32^{\circ} C$} & \multicolumn{2}{|c}{$35^{\circ} C$} & \multicolumn{2}{|c}{$37^{\circ} C$} \\
\hline \multirow{2}{*}{30} & Ischaemic & $0 / 16$ & $(0)$ & $0 / 7$ & $(0)$ & $1 / 17$ & $(6)$ \\
& Control & $1 / 19$ & $(5)$ & $2 / 15$ & $(13)$ & $1 / 18$ & $(6)$ \\
60 & Ischaemic & $2 / 25$ & $(8)$ & $1 / 16$ & $(6)$ & $0 / 2$ & $(0)$ \\
& Control & $0 / 18$ & $(0)$ & $0 / 14$ & $(0)$ & $0 / 20$ & $(0)$ \\
& Ischaemic & $2 / 7$ & $(29)$ & & & & \\
& Control & $0 / 17$ & $(0)$ & $0 / 14$ & $(0)$ & $1 / 13$ & $(8)$ \\
\hline
\end{tabular}

$\%$ equivalents in parentheses.

were similar to those obtained from a group of ten untreated control animals selected at random from the experimental colony $(89 / 106,84 \%)$. In the treated horns, higher abdominal temperatures were associated with lower fetal survival rates in groups clamped for $60 \mathrm{~min}$ (significant at the $P<0.001$ level) and 120 min, where the only survivors were found in the group with the lowest abdominal temperature. There was no apparent temperature effect on groups treated for $30 \mathrm{~min}$, nor were the differences in fetal survival rates between these groups significant. In addition to abdominal temperature, the duration of treatment influenced fetal survival rates in treated horns. After 30 and 60 min, the combined rates were $51 \%$ and $57 \%$, respectively, falling to $9 \%$ after $120 \mathrm{~min}$. 
The combined malformation rate (Table 3) from all treated horns of the nine groups was $6 / 90(7 \%)$ and that from control horns $5 / 148(3 \%)$. The eleven malformed fetuses included seven cases of anophthalmia or microphthalmia and one each of triocephaly, ethnocephaly, cranial vault defect and gastroschisis.

There were significant differences in mean fetal weights from control horns between the nine groups. These differences did not appear to be related to treatment (Table 4) but may have contributed to differences between mean fetal weights from treated horns. To remove this contribution and to assess the weight-retarding effect of treatment, the difference in mean fetal weight between

TABLE 4

MEAN FETAL WEIGHTS AFTER UTERINE ISGHAEMIA AT DIFFERENT ABDOMINAL TEMPERATURES

\begin{tabular}{|c|c|c|c|c|}
\hline \multirow{2}{*}{$\begin{array}{l}\text { Duration of } \\
\text { stasis (min) }\end{array}$} & \multirow{2}{*}{$\begin{array}{l}\text { Uterine } \\
\text { horn }\end{array}$} & \multicolumn{3}{|c|}{ Abdominal temperature } \\
\hline & & $32^{\circ} \mathrm{C}$ & $35^{\circ} \mathrm{C}$ & $37^{\circ} \mathrm{C}$ \\
\hline 30 & $\begin{array}{l}\text { Control } \\
\text { Ischaemic } \\
\text { Difference* }\end{array}$ & $\begin{array}{r}2.67 \pm 0.09(19) \\
2.56 \pm 0.11(16) \\
+0.11\end{array}$ & $\begin{array}{r}3.07 \pm 0.22(15) \\
2.39 \pm 0.09(7) \\
+0.68\end{array}$ & $\begin{array}{r}2 \cdot 69 \pm 0.10(13) \\
2 \cdot 29 \pm 0.07(17) \\
+0.40\end{array}$ \\
\hline 60 & $\begin{array}{l}\text { Control } \\
\text { Ischaemic } \\
\text { Difference* }\end{array}$ & $\begin{array}{r}2 \cdot 74 \pm 0.11(14) \\
2 \cdot 36 \pm 0.10(20) \\
+0.38\end{array}$ & $\begin{array}{r}3.03 \pm 0.06(14) \\
2.37 \pm 0.03(16) \\
+0.66\end{array}$ & $\begin{array}{r}2.99 \pm 0.07 \text { (17) } \\
2.00 \pm 0.32 \text { (2) } \\
+0.99\end{array}$ \\
\hline 120 & $\begin{array}{l}\text { Control } \\
\text { Ischaemic } \\
\text { Difference* }\end{array}$ & $\begin{array}{r}2.38 \pm 0.08(17) \\
1.94 \pm 0.07(1) \\
+0.44\end{array}$ & $2.59 \pm 0.08(14)$ & $2 \cdot 85 \pm 0 \cdot 10(13)$ \\
\hline
\end{tabular}

Three rats were inadvertently killed on Day 22 instead of Day 21. Fetal weights from these rats were not included in the results. The mean weight \pm S.E. in $g$ is given for each group followed by the number of fetuses contributing to the mean in parentheses.

* The difference between mean fetal weight from control, and ischaemic horns.

control and treated horns within each group was calculated. These values (Table 4) tended to increase as the abdominal temperature increased and as the duration of treatment extended. Analysis of variance of the six values from groups treated for 30 and $60 \mathrm{~min}$ showed that the variation due to abdominal temperature was significant $(P<0.05)$ but that variation due to the duration of treatment was not.

There was no indication that the male: female sex ratios of surviving fetuses had been affected by treatment. The combined ratio from treated horns was $45: 45$, and that from control horns $71: 77$.

\section{DISCUSSION}

Differences in abdominal temperature clearly influence the effects of uterine ischaemia, particularly in regard to rates of fetal survival. In groups subjected to 60 min of treatment, fetal survival fell from $81 \%$ at $32^{\circ} \mathrm{C}$, to $70 \%$ at $35^{\circ} \mathrm{C}$, and $10 \%$ at $37^{\circ} \mathrm{C}$. In this laboratory, it was found that rectal temperatures can fall from $37^{\circ} \mathrm{C}$ in the conscious resting animal to $30^{\circ} \mathrm{C}$ in the anaesthetized animal with a ventral midline incision. The amount and rate of fall was dependent largely on room temperature and the degree of exposure of the abdominal 
contents. It is evident that abdominal temperatures should be controlled or specified if valid comparisons between experiments of this nature are to be made.

Franklin \& Brent (1964), who did not state the temperature conditions of their experiment, found that $60 \mathrm{~min}$ of uterine ischaemia had little effect on fetal survival. They suggested that the 9-day rat embryo showed considerable resistance to uterine ischaemia. The present work, however, shows that, if the abdomen is maintained at a temperature similar to the rectal temperature of normal conscious animals at rest, i.e. $37^{\circ} \mathrm{C}$, even $30 \mathrm{~min}$ of ischaemia causes an appreciable reduction in fetal survival. It is clear that the resistance of the embryo to uterine ischaemia must be re-evaluated.

Zhukova \& Purin (1967) reported that a small (unspecified) number of 17to 21-day rat fetuses survived after their umbilical cords had been occluded for up to $60 \mathrm{~min}$, with the mothers maintained between 37 and $38^{\circ} \mathrm{C}$. It is interesting that $10 \%$ of embryos in the present experiment survived the same period of uterine ischaemia at an abdominal temperature of $37^{\circ} \mathrm{C}$. Dawes (1968) has reviewed some of the metabolic reasons for the resistance of the rat fetus to hypoxia, though whether these considerations hold for the 9-day embryo is not known. It must be concluded that rat embryos show a wide range of susceptibility to the conditions imposed by uterine ischaemia.

The fetal weight results provided further evidence that abdominal temperature can influence the effects of uterine ischaemia. In the treated horns, fetal weights were lower at the higher abdominal temperatures.

Malformation rates in the treated horns were twice those in the control horns but the differences were not significantly different. Ischaemia was applied at an age when the embryo was considered to be highly susceptible to malformation (Franklin \& Brent, 1964), and for periods resulting in a range of mortality rates over which teratogenic effects are likely to be manifest (Beck \& Lloyd, 1964). It is possible that breed susceptibility to teratogenesis (Beck \& Lloyd, 1965) may have been operative in the present work, for the malformation rates observed were considerably lower than those reported by Franklin \& Brent (1964).

The blood supply to the ovary was not included in the clamps so that ischaemia probably affected the embryo either directly, or indirectly through changes in the placenta. The temperature of the embryo and placenta must have been close to the experimentally controlled abdominal temperature since the thermometer recording the latter was in close contact with the uterine wall, and the abdominal cavity was usually closed to minimize heat gradients. Within limits, most metabolic reactions proceed faster at higher temperatures. If uterine ischaemia acts by a reduction in the supply of essential substrates or by the accumulation of toxic waste products in the placenta or embryo, or both, then it is only to be expected that increased abdominal temperatures would augment this action.

\section{ACKNOWLEDGMENTS}

This study formed part of a Ph.D. thesis submitted for examination to the University of Melbourne in February 1971. I acknowledge with gratitude the 
constant advice and encouragement of $\mathrm{Dr} \mathrm{J}$. Watson and technical assistance by $\mathrm{Mr} \mathrm{R}$. Condron.

\section{REFERENCES}

BECK, F. \& LLOYD, J. B. (1964) Dosage-response curves for the teratogenic activity of trypan blue. Nature, Lond. 201, 1136.

Beck, F. \& Lloyd, J. B. (1965) Embryological principles of teratogenesis. In: A Symposium on Embryopathic Activity of Drugs, p. 1. Eds. J. M. Robson, F. M. Sullivan and R. L. Smith. Churchill, London.

Csepli, J., Menyhart, J., Lengyel, S., Bodnar, J. \& Turoczi, F. (1968) Blood circulation in pregnant rats. II. Some features of uterine circulation during pregnancy. Acta chir. hung. 9, 143.

Davis, J. S. (1960) Hormonal control of plasma and erythrocyte volumes of rat uterus. Am. F. Physiol. 199,841 .

DAwes, G. S. (1968) Foetal and neonatal physiology, a comparative study of the changes at birth, p. 141. Year Book Medical Publishers, Chicago.

Frankin, J. B. \& BRENT, R. L. (1964) The effect of uterine vascular clamping on the development of rat embryos three to fourteen days old. F. Morph. 115, 273.

George, E. F., Franklin, J. B. \& Brent, R. L. (1967) Altered embryonic effects of uterine vascular clamping in the pregnant rat by uterine temperature control. Proc. Soc. exp. Biol. Med. 124, 257.

WiLson, J. G. (1965) Methods for administering agents and detecting malformations in experimental animals. In: Teratology, Principles and Techniques, p. 262. Eds. J. G. Wilson and J. Warkany. University of Chicago Press.

Zhukova, T. P. \& Purin, V. R. (1967) Method of producing isolated asphyxia of the fetus. Bull. exp. Biol. Med. U.S.S.R. 64, 800. 